\title{
Ionic Liquid-Mediated, Rapid $N$-Alkylation of Heterocyclic Compounds with Trialkyl Phosphites in the Presence of Dialkyl Acetylenedicarboxylates
}

\author{
ALIREZA HASSANABADI ${ }^{* 1}$, MOHAMMAD H. MOSSLEMIN ${ }^{2}$, \\ MOHAMMAD ANARY-ABBASINEJAD ${ }^{3}$, AZADEH KALANTARINEJAD ${ }^{2}$, \\ AND MOZHDEH JERJISI SHIRAZI ${ }^{2}$ \\ ${ }^{* 1}$ Department of Chemistry, Islamic Azad University \\ Zahedan Branch, P.O. Box 98135-978, Zahedan, Iran \\ ${ }^{2}$ Department of Chemistry, Islamic Azad University \\ Yazd Branch, P.O. Box 89195-155, Yazd, Iran \\ ${ }^{3}$ Department of Chemistry, Rafsanjan Vali-e-Asr University, \\ Rafsanjan, P.O. Box 77176, Iran \\ ar_hasanabadi@yahoo.com
}

Received 31 July 2011; Accepted 4 October 2011

\begin{abstract}
Ionic liquids such as 1,3-dialkylimidazolium bromides and make excellent solvents for $\mathrm{N}$-alkylation of heterocyclic compounds such as saccharin and rhodanine with trialkyl phosphites in the presence of dialkyl acetylenedicarboxylates.
\end{abstract}

Keywords: Ionic liquids, $N$-Alkylation, Heterocyclic compounds, Dialkyl acetylene dicarboxylates, Trialkyl phosphites.

\section{Introduction}

Ionic liquids (ILs) have attracted considerable attention in recent years due to their unique properties, such as lack of measurable vapor pressure, non-flammability and recyclability ${ }^{1}$. Their high polarity and ability to dissolve both inorganic and organic materials can result in enhanced rates of chemical processes and can provide higher/different selectivities compared to conventional solvents. Thus, as a result of their 'green' credentials and potential to enhance rate and selectivity ${ }^{2,3}$, ILs have been used as solvents in chemical transformations. However, the ability of ILs to serve as catalysts ${ }^{4}$ and reagents ${ }^{5}$ has not been explored to any great extent ${ }^{6,7}$.

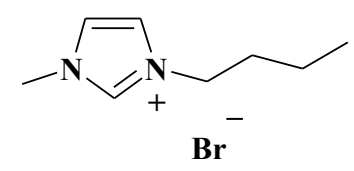

Ionic liquids: [bmim][Br]

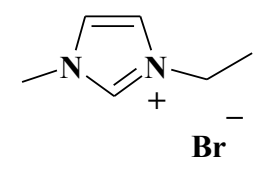

$[\mathrm{emim}][\mathrm{Br}]$

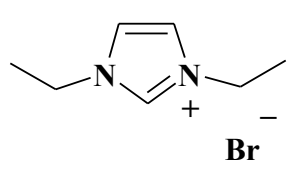

[eeim] $[\mathrm{Br}]$ 
$\mathrm{N}$-Substitution and benzene moiety functionalization are significant components of the strategic approach to the saccharin ring system. Various methods of $\mathrm{N}$-alkylation of saccharin sodium have already been developed, using either conventional heating or microwave irradiation in dry media and in dimethylformamide (DMF $)^{8-11}$. The anionic form of saccharin is ambifunctional, so the saccharin anion may react via the nitrogen or the oxygen in a nucleophilic reaction, depending on such factors as temperature, the electrophile used, the cation, and the solvent. A major distinction to be made for nucleophilic reactions with ambident anions is whether they proceed under kinetic or thermodynamic control. Alkylation at the more electronegative atom of an ambident ion generally increases with SN1 character of the reaction; however, alkyl halides ordinarily react at the less electronegative nitrogen atom to form $N$-substituted saccharins, which are the thermodynamically more stable products ${ }^{12}$. The $\mathrm{N}$-alkylation of heterocyclic compounds bearing an acidic hydrogen atom attached to nitrogen is generally accomplished by treatment of these compounds with an appropriate base (sodium hydroxide or amide, metaloorganic compounds) followed by treatment of the resulting salts with an alkylating agent ${ }^{13}$. All these procedures require strictly anhydrous conditions and use of strongly ionizing solvents ${ }^{14}$. The problems in the reported protocols such as prolonged reaction time, poor yields, use of hazardous solvents, and industrially impracticable microwave heating prompted us to develop a convenient, three-component, one-pot environmentally acceptable method for $\mathrm{N}$-alkylation of heterocyclic compounds such as saccharin and rhodanine with trialkyl phosphites in the presence of dialkyl acetylenedicarboxylates.

\section{Experimental}

Melting points were determined with an Electrothermal 9100 apparatus. Elemental analyses were performed using a Costech ECS 4010 CHNS-O analyzer at analytical laboratory of Islamic Azad University yazd branch. ${ }^{1} \mathrm{H},{ }^{13} \mathrm{C}$ and spectra were recorded on BRUKER DRX-500 AVANCE spectrometer in $\mathrm{CDCl}_{3}$ using TMS as internal standard. The chemicals used in this work were purchased from Fluka (Buchs, Switzerland) and were used without further purification.

\section{General Procedure for Preparation of Compounds (4a-f)}

An equimolar mixture of trialkyl phosphite and saccharin was dissolved in ionic liquid $(1 \mathrm{~g})$ and the solution was stirred for $5 \mathrm{~min}$ at $100^{\circ} \mathrm{C}$. Then was added dropwise a mixture of dialkyl acetylenedicarboxylate and the reaction content was allowded to stir at $100^{\circ} \mathrm{C}$ for $8 \mathrm{~h}$. The progress of the reaction was monitored by thin-layer chromatography (TLC). After completion of the reaction, the reaction mixture was cooled at room temperature and poured into ice water. The solid precipitated was filtered and dried. The purity of the products was confirmed by TLC.

\section{Recovery of the Ionic Liquid}

An attempt was made to recover the ionic liquid. After completion of the reaction, the reaction mixture was poured on ice water, and the product was filtered off. The filtrate was extracted with ethyl acetate to recover unreacted reactants, and the aqueous layer was subjected to evaporation of water to get viscous liquid, which on cooling gave the ionic liquid. The recovered ionic liquid was reused for two more cycles of the same cyclocondensation and found to act satisfactorily.

\section{2-Methyl-1,1-dioxo-1,2-dihydro-1lambda*6*-benzo[d]isothiazol-3-one (4a)}

Yield: 90\%; White Powder, m.p. $133-135^{\circ} \mathrm{C}, \mathrm{IR}(\mathrm{KBr})\left(v_{\max }, \mathrm{cm}^{-1}\right): 1734(\mathrm{C}=\mathrm{O}$, amide). Analyses: Calcd. for $\mathrm{C}_{8} \mathrm{H}_{7} \mathrm{NO}_{3} \mathrm{~S}, 197$ : C, 48.72; H, 3.58; N, 7.10\%. Found: C, 48.85; H, 3.48; N, $7.00 \% .{ }^{1} \mathrm{H}$ NMR $\left(500 \mathrm{MHz}, \mathrm{CDCl}_{3}\right): \delta 3.26\left(\mathrm{~s}, 3 \mathrm{H}, \mathrm{CH}_{3}\right), 7.81-8.07(4 \mathrm{H}, \mathrm{m}, 4 \mathrm{CH}$ aromatic). ${ }^{13} \mathrm{C}$ NMR $\left(125.8 \mathrm{MHz}, \mathrm{CDCl}_{3}\right): \delta 23.69\left(\mathrm{CH}_{3}\right), 121.44,125.57,128.03,134.78$, $135.11,138.05$ (6 $\mathrm{C}$ aromatic), $159.15(\mathrm{C}=\mathrm{O})$. 


\section{2-Ethyl-1,1-dioxo-1,2-dihydro-1lambda ${ }^{*} 6^{*}$-benzo[d]isothiazol-3-one (4b)}

Yield: $88 \%$; White Powder, m.p. $129-131^{\circ} \mathrm{C}, \mathrm{IR}(\mathrm{KBr})\left(v_{\max }, \mathrm{cm}^{-1}\right): 1730(\mathrm{C}=\mathrm{O}$, amide). Analyses: Calcd. for $\mathrm{C}_{9} \mathrm{H}_{9} \mathrm{NO}_{3} \mathrm{~S}, 211$ : C, 51.17; H, 4.29; N, 6.63\%. Found: C, 51.07; H, 4.40; $\mathrm{N}, 6.78 \% .{ }^{1} \mathrm{H}$ NMR $\left(500 \mathrm{MHz}, \mathrm{CDCl}_{3}\right): \delta 1.46\left(3 \mathrm{H}, \mathrm{t}^{3} \mathrm{~J}_{\mathrm{HH}}=7 \mathrm{~Hz}, \mathrm{CH}_{3}\right), 3.88\left(2 \mathrm{H}, \mathrm{q}^{3} J_{\mathrm{HH}}=7\right.$ $\left.\mathrm{Hz}, \mathrm{CH}_{2}\right), 7.83-8.09$ (4H, m, $4 \mathrm{CH}$ aromatic). $\left.{ }^{13} \mathrm{C} \mathrm{NMR} \mathrm{(125.8} \mathrm{MHz,} \mathrm{CDCl}_{3}\right): \delta 14.35\left(\mathrm{CH}_{3}\right)$, $34.61\left(\mathrm{CH}_{2}\right), 121.29,125.45,127.93,134.69,135.07,138.22(6 \mathrm{C}$ aromatic $), 159.11(\mathrm{C}=\mathrm{O})$.

\section{2-Butyl-1,1-dioxo-1,2-dihydro-1lambda ${ }^{*} 6^{*}$-benzo[d]isothiazol-3-one(4c)}

Yield: 92\%; White Powder, m.p. $138-140^{\circ} \mathrm{C}, \mathrm{IR}(\mathrm{KBr})\left(v_{\max }, \mathrm{cm}^{-1}\right): 1728(\mathrm{C}=\mathrm{O}$, amide). Analyses: Calcd. for $\mathrm{C}_{11} \mathrm{H}_{13} \mathrm{NO}_{3} \mathrm{~S}, 239$ : C, 55.21; H, 5.48; N, 5.85\%. Found: C, 5.33; H, 5.69; N, 5.72\%. ${ }^{1} \mathrm{H}$ NMR (500 MHz, $\left.\mathrm{CDCl}_{3}\right): \delta 0.97\left(3 \mathrm{H}, \mathrm{t}^{3} \mathrm{~J}_{\mathrm{HH}}=7 \mathrm{~Hz}, \mathrm{CH}_{3}\right), .43(2 \mathrm{H}$, sextet, $\left.{ }^{3} J_{\mathrm{HH}}=7 \mathrm{~Hz}, \mathrm{CH}_{2}\right), 1.83\left(2 \mathrm{H}\right.$, quintet, $\left.{ }^{3} J_{\mathrm{HH}}=7 \mathrm{~Hz}, \mathrm{CH}_{2}\right), 3.77\left(2 \mathrm{H}, \mathrm{t}^{3} J_{\mathrm{HH}}=7 \mathrm{~Hz}\right.$, $\left.\mathrm{CH}_{2}\right), 7.50-8.06\left(4 \mathrm{H}, \mathrm{m}, 4 \mathrm{CH}\right.$ aromatic). ${ }^{13} \mathrm{C} \mathrm{NMR}\left(125.8 \mathrm{MHz}, \mathrm{CDCl}_{3}\right): \delta 13.84\left(\mathrm{CH}_{3}\right)$, $20.48\left(\mathrm{CH}_{2}\right), 30.70\left(\mathrm{CH}_{2}\right), 39.15\left(\mathrm{CH}_{2}\right), 121.30,125.52,127.92,134.68,135.06,138.17(6 \mathrm{C}$ aromatic), $159.40(\mathrm{C}=\mathrm{O})$.

\section{3-Methyl-2-thioxo-thiazolidin-4-one(4d)}

Yield: 90\%; Yellow Oil, IR $(\mathrm{KBr})\left(v_{\max }, \mathrm{cm}^{-1}\right)$ : $1716(\mathrm{C}=\mathrm{O}$, amide). Analyses: Calcd. for $\mathrm{C}_{4} \mathrm{H}_{5} \mathrm{NOS}_{2}$, 147: C, 32.63; H, 3.42; N, 9.51\%. Found: C, 32.50; H, 3.35; N, 9.62\%. ${ }^{1} \mathrm{HNMR}$ $\left(500 \mathrm{MHz}, \mathrm{CDCl}_{3}\right): \delta 3.46\left(\mathrm{~s}, 3 \mathrm{H}, \mathrm{CH}_{3}\right), 3.98(\mathrm{~s}, 2 \mathrm{H}, \mathrm{CH} 2, \mathrm{C} 3 \mathrm{H} 2 \mathrm{NOS} 2) \mathrm{ppm} .{ }^{13} \mathrm{C} \mathrm{NMR}$ $\left(125.8 \mathrm{MHz}, \mathrm{CDCl}_{3}\right): \delta 23.87\left(\mathrm{CH}_{3}\right), 45.09\left(\mathrm{C}_{3} \mathrm{H}_{2} \mathrm{NOS}_{2}\right), 174.64(\mathrm{C}=\mathrm{O}), 201.48(\mathrm{C}=\mathrm{S}) \mathrm{ppm}$.

\section{3-Ethyl-2-thioxo-thiazolidin-4-one(4e)}

Yield: $89 \%$; Yellow Oil, IR $(\mathrm{KBr})\left(v_{\max }, \mathrm{cm}^{-1}\right)$ : $1716(\mathrm{C}=\mathrm{O}$, amide $)$. Analyses: Calcd. for $\mathrm{C}_{5} \mathrm{H}_{7} \mathrm{NOS}_{2}, 161$ : C, 37.24; H, 4.38; N, 8.69\%. Found: C, 37.32; H, 4.50; N, 8.55. ${ }^{1} \mathrm{HNMR}$ $\left(500 \mathrm{MHz}, \mathrm{CDCl}_{3}\right): \delta 1.52\left(3 \mathrm{H}, \mathrm{t}^{3} J_{\mathrm{HH}}=7 \mathrm{~Hz}, \mathrm{CH}_{3}\right), 3.96\left(2 \mathrm{H}, \mathrm{q}^{3} J_{\mathrm{HH}}=7 \mathrm{~Hz}, \mathrm{CH}_{2}\right), 3.90$ (s, 2H, CH2, C3H2NOS2) ppm. ${ }^{13} \mathrm{C}$ NMR $\left(125.8 \mathrm{M} \mathrm{Hz}, \mathrm{CDCl}_{3}\right): \delta 14.31\left(\mathrm{CH}_{3}\right), 34.73$ $\left(\mathrm{CH}_{2}\right), 45.05\left(\mathrm{C}_{3} \mathrm{H}_{2} \mathrm{NOS}_{2}\right), 174.48(\mathrm{C}=\mathrm{O}), 201.38(\mathrm{C}=\mathrm{S}) \mathrm{ppm}$.

\section{3-Butyl-2-thioxo-thiazolidin-4-one(4f)}

Yield: 91\%; Yellow Oil, IR $(\mathrm{KBr})\left(v_{\max }, \mathrm{cm}^{-1}\right)$ : $1716(\mathrm{C}=\mathrm{O}$, amide). Analyses: Calcd. for $\mathrm{C}_{7} \mathrm{H}_{11} \mathrm{NOS}_{2}, 189$ : C, 44.42; H, 5.86; N, 7.40\%. Found: C, 44.53; H, 6.01; N, 7.57. ${ }^{1} \mathrm{HNMR}$ $\left(500 \mathrm{MHz}, \mathrm{CDCl}_{3}\right): \delta 0.93\left(3 \mathrm{H}, \mathrm{t}{ }^{3} J_{\mathrm{HH}}=7 \mathrm{~Hz}, \mathrm{CH}_{3}\right), 1.35\left(2 \mathrm{H}\right.$, sextet, $\left.{ }^{3} J_{\mathrm{HH}}=7 \mathrm{~Hz}, \mathrm{CH}_{2}\right)$, $1.62\left(2 \mathrm{H}\right.$, quintet, $\left.{ }^{3} J_{\mathrm{HH}}=7 \mathrm{~Hz}, \mathrm{CH}_{2}\right), 3.96\left(2 \mathrm{H}, \mathrm{t}^{3} J_{\mathrm{HH}}=7 \mathrm{~Hz}, \mathrm{CH}_{2}\right), 3.98(\mathrm{~s}, 2 \mathrm{H}, \mathrm{CH} 2$, C3H2NOS2) ppm. ${ }^{13} \mathrm{C}$ NMR $\left(125.8 \mathrm{MHz}, \mathrm{CDCl}_{3}\right): \delta 14.07\left(\mathrm{CH}_{3}\right), 20.46\left(\mathrm{CH}_{2}\right), 29.19$ $\left(\mathrm{CH}_{2}\right), 35.77\left(\mathrm{CH}_{2}\right), 45.00\left(\mathrm{C}_{3} \mathrm{H}_{2} \mathrm{NOS}_{2}\right), 174.30(\mathrm{C}=\mathrm{O}), 201.65(\mathrm{C}=\mathrm{S}) \mathrm{ppm}$.

\section{Results and Discussion}

The reaction of DAAD 3 with trialkyl phosphite $\mathbf{2}$ in the presence of saccharin or rhodanine $\mathbf{1}$ in ILs as solvent leds to rapid $N$-alkylation of those in high yields (Figure 1). When saccharin or rhodanine was added to trialkyl phosphites in the absence of dialkyl acetylenedicarboxylate, no product was detected. Products 4a-f was all new compounds and their structures were deduced from their elemental analyses and spectral data. The ${ }^{1} \mathrm{HNMR}$ spectrum of compound $\mathbf{4 a}$ displayed one singlet at $3.26 \mathrm{ppm}$ for methyl group. Aromatic protons resonate between 7.81 and $8.07 \mathrm{ppm}$ as multiplets. The ${ }^{13} \mathrm{C}$ NMR spectrum of compound 4a showed eight distinct resonances in agreement with the proposed structure. The structural assignments made on the basis of the NMR spectra of compound 4a were supported by its IR spectrum, the amid carbonyl groups exhibited strong absorption bands at $1734 \mathrm{~cm}^{-1}$. 
<smiles>O=C1NS(=O)(=O)c2ccccc21</smiles>

or<smiles>O=C1CSC(=S)N1</smiles>

1<smiles>[R]OC#CC#CC(=O)O[R]</smiles>

3<smiles>[R]N1C(=O)c2ccccc2S1(=O)=O</smiles>

or<smiles>[R]N1C(=O)CSC1=S</smiles>

4

\begin{tabular}{l|lll}
$\mathbf{4}$ & $\mathrm{R}$ & $\mathrm{R}^{\prime}$ & \% Yield \\
\hline $\mathbf{a}$ & $\mathrm{Me}$ & $\mathrm{CH}_{3}$ & 90 \\
$\mathbf{b}$ & $\mathrm{Et}$ & $\mathrm{C}_{2} \mathrm{H}_{5}$ & 88 \\
$\mathbf{c}$ & $\mathrm{Bu}$ & $\mathrm{CH}_{3}$ & 92 \\
$\mathbf{d}$ & $\mathrm{Me}$ & $\mathrm{CH}_{3}$ & 90 \\
$\mathbf{e}$ & $\mathrm{Et}$ & $\mathrm{C}_{2} \mathrm{H}_{5}$ & 89 \\
$\mathbf{f}$ & $\mathrm{Bu}$ & $\mathrm{CH}_{3}$ & 91
\end{tabular}

4a-c: Saccharin and 4d-f: Rhodanine.

Figure 1. $N$ Alkylation of saccharin or rhodanine with trialkyl phosphites in the presence of dialkyl acetylenedicarboxylate in ILs as solvent.

Although we have not yet established the mechanism of the reaction between trialkyl phosphites and acetylenes in the presence of saccharin or rhodanine in an experimental manner, a plausible explanation is proposed in Figure 2. On the basis of the well established chemistry of phosphorus nucleophiles ${ }^{15-20}$, it is reasonable to assume that compounds $4 \mathbf{a}$ result from initial addition of trimethyl phosphite to the activated acetylene and subsequent protonation of the reactive 1:1 adduct by saccharin, followed by attack of anion $\mathbf{5}$ at the methyl group of the cation 6 to generate $4 a$.

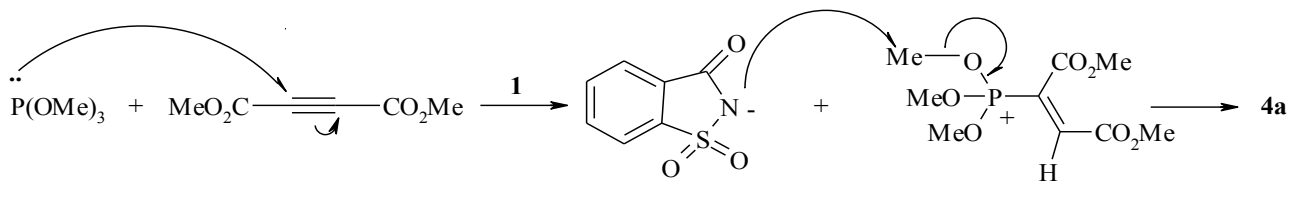

2

Figure 2. Suggested mechanism for formation of compound $\mathbf{4 a}$.

The present method carries the advantage that, not only is the reaction performed under neutral conditions, but the educts can be mixed without any activation or modification.

\section{Conclusion}

In summary, we report herein that Ionic liquids such as 1, 3-dialkylimidazolium bromides and make excellent solvents for $\mathrm{N}$-alkylation of heterocyclic compounds such as saccharin and rhodanine with trialkyl phosphites in the presence of dialkyl acetylenedicarboxylates in high yields. 


\section{Acknowledgment}

We gratefully acknowledge financial support from the Research Council of Islamic Azad University of Zahedan and The Islamic Azad University of Yazd of Iran.

\section{References}

1. Welton T, Chem Rev., 1999, 99, 2071.

2. Wasserscheid $\mathrm{P}$ and Welton T, Ionic Liquids in Synthesis, Eds., Wiley-VCH: Weinheim, Germany, 1987.

3. Dupont J, de Souza R F, and Suarez P A Z, Chem Rev., 2002, 102, 3667.

4. Harjani J R, Nara S J, and Salunkhe M M, Tetrahedron Lett., 2002, 43, 1127.

5. Ranu B C, Das A, and Samanta S, J Chem Soc Perkin Trans., 1, 2002, 1520.

6. Ranu B C and Banerjee S, J Org Chem., 2005, 70, 4517.

7. Walborsky H M and Hornyak F M, J Am Chem Soc., 1955, 77, 6396.

8. Soler L, Cerrada V, Matı'a M P, Novella J L, and Alvarez-Builla J, Arkivoc, 2007, iv, 312.

9. Lombardino J G, Wiseman E H, and Mclamore W, J Med Chem., 1971, 14, 1171.

10. Fiorino F, Caliendo G, Perissutti E, Severino B, Frecentese F, Preziosi B, Izzo A A, Capasso R, and Santagada V, Arch Pharm Chem Life Sci., 2005, 338, 548.

11. Ding J, Gu H, Wen J, and Lin C, Synth Comm., 1994, 24, 301.

12. Hettler H, Katritzky A R, and Burton A J, In Advances in Heterocyclic Chemistry, (Eds.); Academic Press: New York, 1973, 15, 233-276.

13. Gilchrist T L, Heterocyclic Chemistry, $2^{\text {nd }}$ Ed., Longman, London, 1992.

14. Barco A, Benetti S, and Pollini G P, Synthesis, 1976, 124.

15. Holmes R R, Acc Chem Res., 2004, 37, 746.

16. Maryanoff B E and Reitz A B, Chem Rev., 1989, 89, 863.

17. Yavari I, Anary-Abbasinejad M and Hossaini Z, Org Biomol Chem., 2003, 3, 560.

18. Anary-Abbasinejad M and Hassanabadi A, J Chem Res., 2007, 475.

19. Anary-Abbasinejad M, Hassanabadi A, and Mazraeh-Seffid M, J Chem Res., 2007, 708.

20. Anary-Abbasinejad M, Charkhati K, and Hassanabadi A, J Chem Res., 2009, 319. 


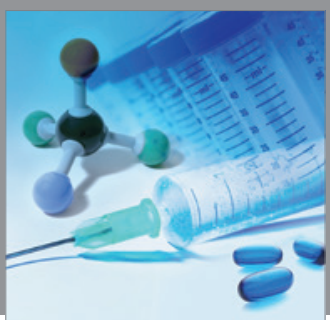

International Journal of

Medicinal Chemistry

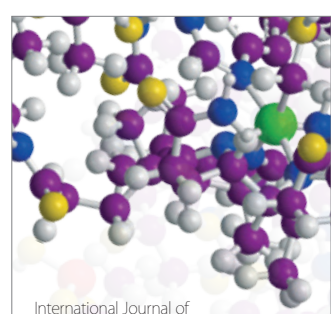

Carbohydrate Chemistry

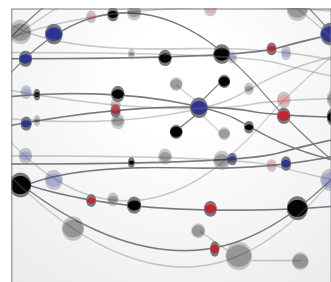

The Scientific World Journal
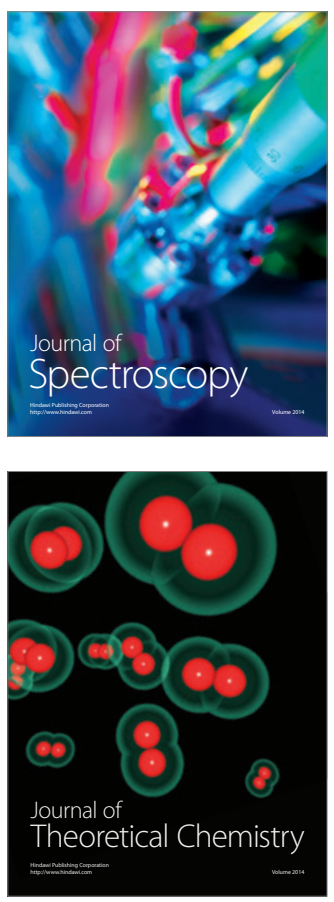
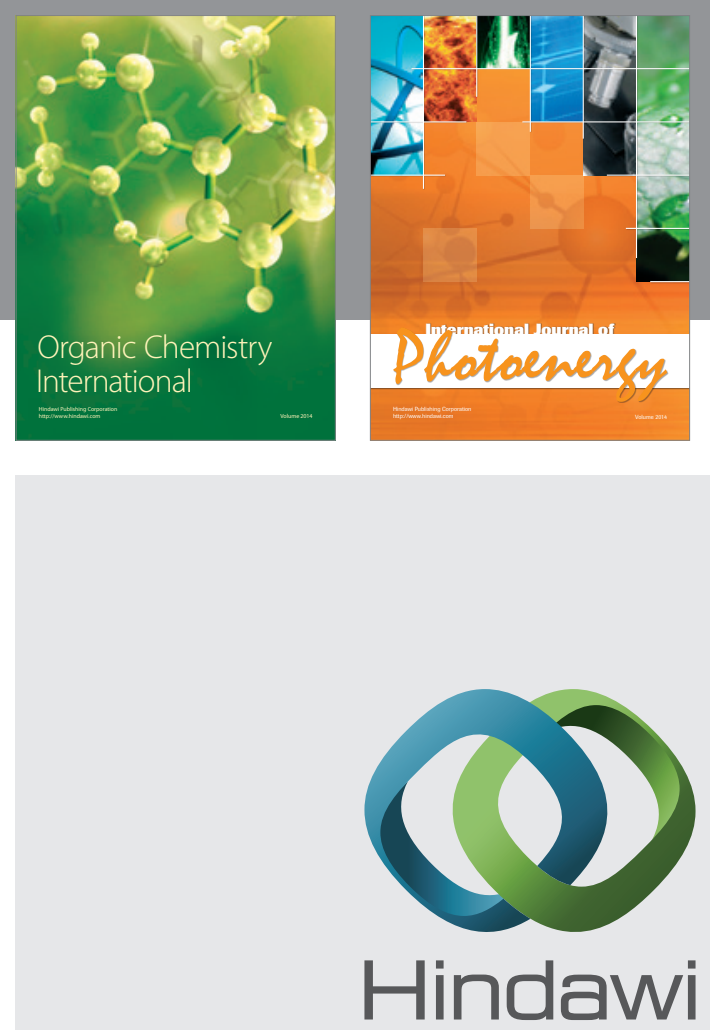

Submit your manuscripts at

http://www.hindawi.com
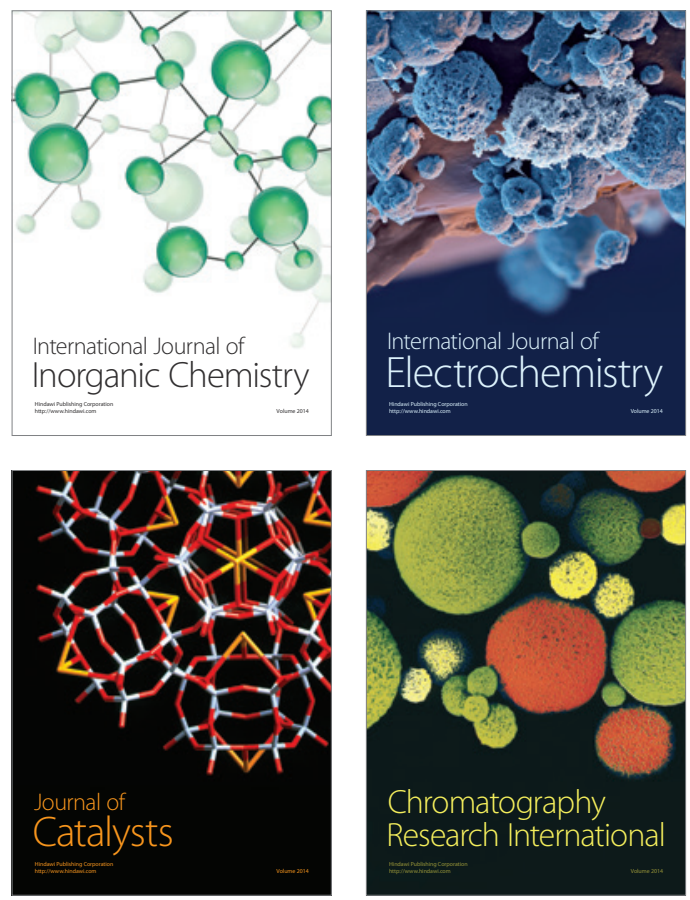
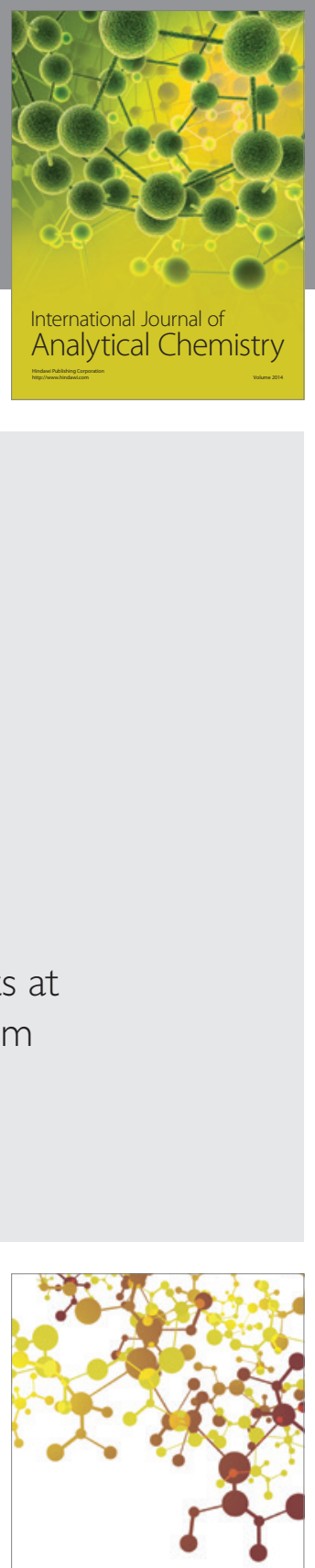

Journal of

Applied Chemistry
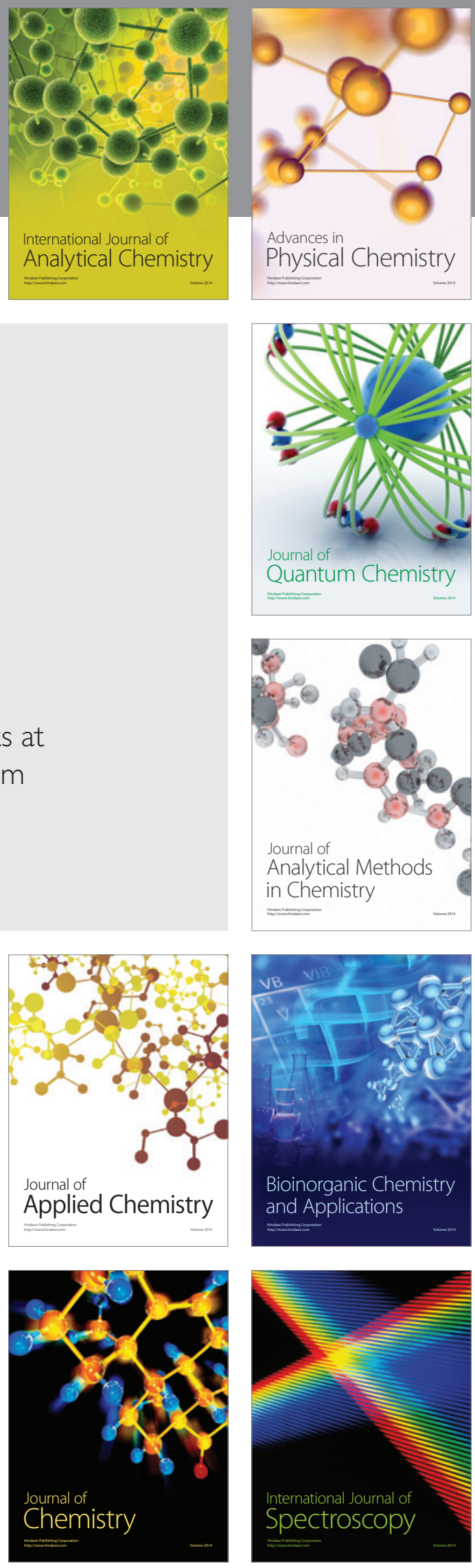